\title{
Re-description and range extension of the Afrotropical mayfly Cloeon perkinsi (Ephemeroptera, Baetidae)
}

\author{
Zohar YANAI ${ }^{1, *}$, Wolfram GRAF ${ }^{2}$, Yonas TEREFE ${ }^{3}$, \\ Michel SARTORI ${ }^{4} \&$ Jean-Luc GATTOLLIAT ${ }^{5}$ \\ 1,4,5 Musée Cantonal de Zoologie, Palais de Rumine, Lausanne, Switzerland. \\ 1,4,5 Department of Ecology and Evolution, Biophore, \\ University of Lausanne, 1015 Lausanne, Switzerland. \\ ${ }^{1}$ School of Zoology, Tel Aviv University, Tel Aviv 6997801, Israel. \\ ${ }^{2,3}$ University of Natural Resources and Applied Life Sciences, Institute of \\ Hydrobiology and Aquatic Ecology Management, Vienna, Austria. \\ ${ }^{3}$ Department of Biology, College of Natural and Computational \\ Sciences, Ambo University, Ambo, Ethiopia. \\ *Corresponding author: yanai.zohar@gmail.com \\ ${ }^{2}$ Email: wolfram.graf@boku.ac.at \\ ${ }^{3}$ Email: Yonasterefe56@gmail.com \\ ${ }^{4}$ Email: michel.sartori@vd.ch \\ ${ }^{5}$ Email: jean-luc.gattolliat@vd.ch \\ ${ }^{1}$ urn:lsid:zoobank.org:author:8051A9A6-95B7-42CD-A6F9-B100022CBDDF
${ }^{2}$ urn:1sid:zoobank.org:author:B658E6F2-A8FB-4819-81E0-ACCACB669407
${ }^{3}$ urn:lsid:zoobank.org:author:AF7B5B55-F553-494A-99AA-F6F965E92E98
${ }^{4}$ urn:1sid:zoobank.org:author:D41D06EA-EF27-40C6-AE14-64F21A3D65D4
${ }^{5}$ urn:1sid:zoobank.org:author:9F2CBF71-33B8-4CD7-88D3-85D7E528AEA5
}

\begin{abstract}
Cloeon perkinsi was described from South Africa in 1932 by Barnard. Despite being relatively common in Africa, it was mentioned in the literature quite rarely, and its known distribution to date includes most of sub-Saharan Africa. Material collected recently in Ethiopia, Israel, Saudi Arabia, and Yemen extends its distribution in East Africa, Arabian Peninsula and the Levant. We examined this material, and provide a re-description of adults (females and males) and nymphs of the species. It represents a much-needed urge mainly due to inconsistencies in literature reports regarding colouration, and sometimes incomplete morphological description of all stages. We demonstrate the intraspecific morphological variability that we have witnessed, and provide information regarding the range of habitats colonised by $C$. perkinsi. Based on geological and climatic history of the studied region, taken together with among countries genetic distances of the mitochondrial barcoding gene COI, we propose colonisation mechanisms for the north-easternmost limit of distribution. The fragmented distribution pattern of the species highlights the conservation importance of isolated aquatic habitats in the region, as well as current knowledge gaps.
\end{abstract}

Keywords. Afrotropics, Arabian Peninsula, biogeography, Cloeon, Levant. 
Yanai Z., Graf W., Terefe Y., Sartori M. \& Gattolliat J. 2020. Re-description and range extension of the Afrotropical mayfly Cloeon perkinsi (Ephemeroptera, Baetidae). European Journal of Taxonomy 617: 1-23. https://doi.og/10.5852/ejt.2020.617

\section{Introduction}

Cloeon perkinsi Barnard, 1932 was described based on a specimen(s) collected in the town of Worcester, South Africa, on April 1931, by A.C. Harrison. No information is given regarding type material or where it is deposited. Following its description, it was reported from further localities in South Africa (Barnard 1940), Malawi (Kimmins 1955), Uganda and Tanzania (Kimmins 1960), Kenya (Demoulin 1965 as Cloeon sp. no. 1), Ghana (Thomas 1966), Gambia, and Nigeria (Gillies 1980). It is considered as the most common and widespread Cloeon species in Afrotropics (Gillies 1980, 1985).

Life stages of C. perkinsi were described separately, and by different authors: Barnard (1932) described the adult female; he also had adult males in his possession (Barnard 1940), but this stage was only later described by Kimmins (1960). Gillies (1980) completed with the description of the nymph. Adults of the species are noticeable among Baetidae mayflies, especially due to their distinguishable body pattern, and female wing pattern (Fig. 1). Nevertheless, the male form was described from East Africa (Kimmins 1960), a distance of thousands of kilometers from the species' type locality in South Africa (Fig. 2). The nymph was first illustrated by Demoulin (1965), but only associated with the correct species and clearly described for the first time much later, by Gillies (1980). It is reasonable to believe that the species mentioned from East and West Africa are the same, since they were studied by the same author (Gillies 1980, 1985), but whether they are the same as Barnard's species from South Africa remains unverified.

The typical habitat of $C$. perkinsi nymphs is variable, and includes standing and running waters, from temporary ponds to the margins of large lakes (Gillies 1980); collecting sites include cities and towns usually in the vicinity of lakes, reservoirs, and streams (Barnard 1940; Kimmins 1960; Thomas 1966; Gillies 1980, 1985). A gynandromorph was observed by Gillies (1980). Knowledge about the species biology is also scarce, but a few sporadic observations teach us that $C$. perkinsi females can live up to 54 days after emergence from the nymph, are ovoviviparous, and that adults perform early morning swarming (Barnard 1940; Gillies 1985). Adults were collected in South Africa in the months Nov.-Jan. and Mar.-Apr. (Barnard 1940) and in East Africa in the months Apr. and Jun.-Aug. (Kimmins 1955, 1960).

Mayflies (order Ephemeroptera) are semi-aquatic short-living insects, therefore highly dependent on freshwater. Their distribution patterns are usually interrupted by unsuitable landscapes, such as seas and arid deserts. One of the most common and widespread mayfly genera is Cloeon Leach, 1815, with more than 70 described species to date known from all continents except Antarctica (Barber-James et al. 2008; Kluge 2019). It mainly colonises standing and slow-running waters; the imaginal stages are unusually long for a mayfly as they can last up to a few weeks. While most Cloeon species are widely distributed (e.g., Afrotropical C. smaeleni Lestage, 1924 or Palaearctic C. simile Eaton, 1870), recent molecular studies proved that part of them are in fact species complexes, which include numerous cryptic species with narrower distribution ranges (see for example Cloeon dipterum s.lat. in Rutschmann et al. 2014, 2017). Recently, Cloeon species are being described from isolated populations in islands and island-like systems (e.g., Cape Verde; Soldán \& Bojková 2015), supporting the understanding that some Cloeon species are actually limited in dispersal capacity and may be sensitive to environmental conditions.

Recently, a few populations of $C$. perkinsi have been sampled independently on the Arabian Peninsula, in Ethiopia and Israel. Interestingly, these mayflies come from few allopatric populations, which are as distant as $2700 \mathrm{~km}$ and not hydrologically connected (Fig. 2). In Israel, the main collecting site is 
the Hula Nature Reserve, a restored swamp area in a matrix of rural landscape, network of irrigation canals and streams (Fig. 3A, D). Collecting sites (elevation $\sim 65 \mathrm{~m}$ a.s.1.) were visited numerous times in different seasons, and environmental parameters were variable (mostly standing waters, with 76$147 \%$ dissolved oxygen, electric conductivity $\sim 500 \mu \mathrm{S}, \mathrm{pH} 7.7-8.8$ ). This site is a tropical-like enclave in the Levant, sustaining some endemic extant or recently extinct tropical species (e.g., species of Cyprinidae and Cichlidae fishes, Glossiphoniidae leeches, Libellulidae dragonflies, and Belostomatidae hemipterans; see Dumont 1991, Dimentman et al. 1992 and Goren \& Ortal 1999). Additional erratic individuals were also collected in sites in the coastal plain of Israel (170 km distant of the main site); repeated collecting efforts in these sporadic sites in the past years yielded no more than three individuals per site. In the Ethiopian Rift Valley, material was sampled in a restricted number of sites along the Awash River (Fig. 3B, E). Collecting sites (elevation up to $2000 \mathrm{~m}$ a.s.1.) were situated in a wide river $(47-90 \mathrm{~m})$, with running waters and a few deep pools, with alkaline $(\mathrm{pH} 8.7)$, well oxygenised (97$120 \%$ dissolved oxygen) waters. In Saudi Arabia, habitats include permanent streams with riparian herbaceous vegetation in semi-arid areas (Fig. 3C, F). An additional population has been sampled in Yemen, where no information is available about the exact locality and its ecological features. In
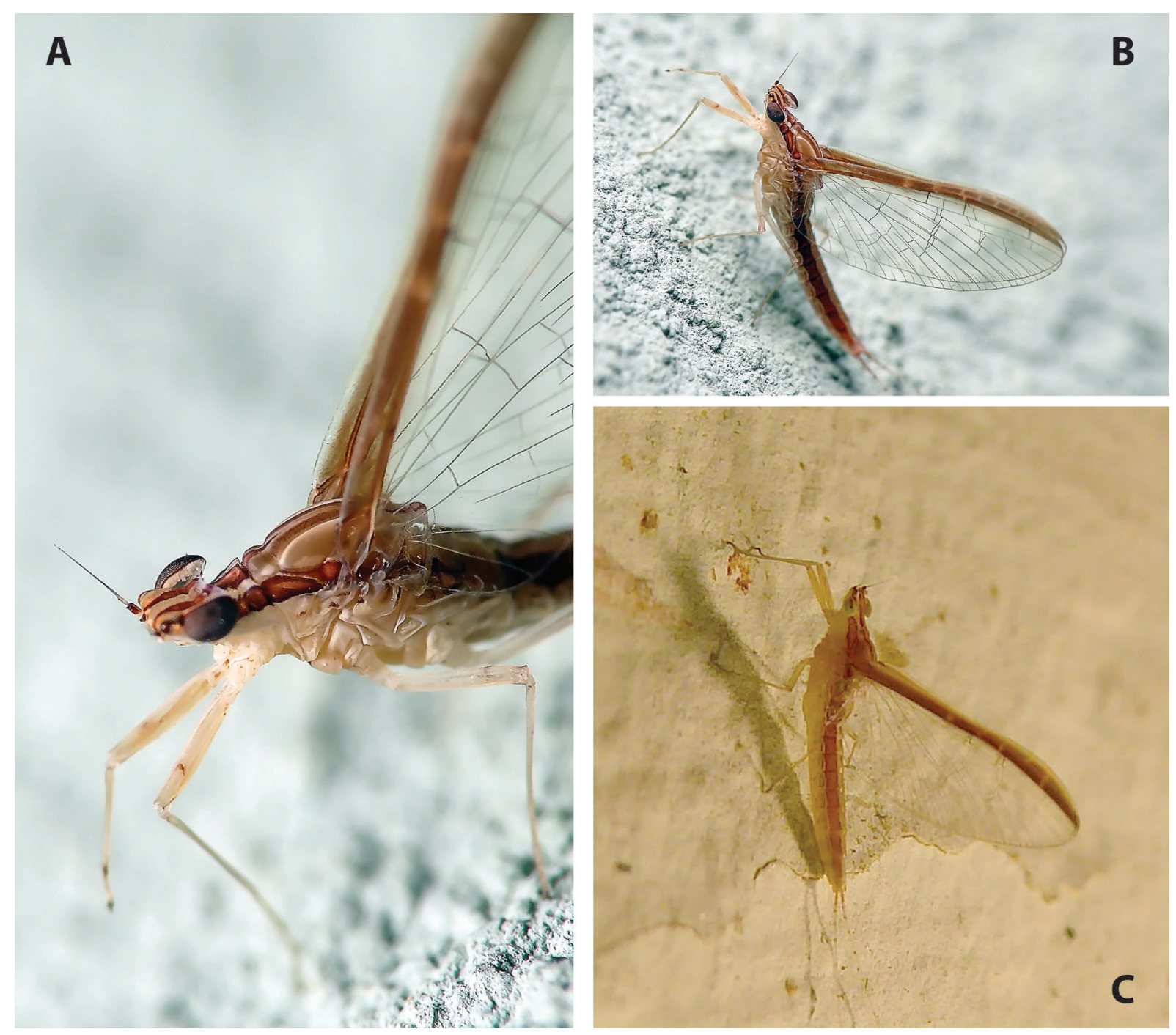

Fig. 1. Cloeon perkinsi adult female in vivo. A-B. Photos taken near Johannesburg, South Africa by Pieter Kotzee. C. Photo taken in Gaborone, Botswana by Christine Sydes. (C published on www.iNaturalist.org) 
addition to this collected material, high quality photographs taken by hobbyists were received or found via Internet search, which suggest that $C$. perkinsi is also found in the vicinity of Johannesburg, South Africa and Gaborone, Botswana. These specimens were not collected and hence not studied in the lab. All of these localities have never before been reported for C. perkinsi.

The only Cloeon species reported from Israel and Jordan is C. dipterum s.lat. (Linnaeus, 1761) (Samocha 1972; Gattolliat et al. 2012); three species (additionally to C. perkinsi) are in fact known from Israel (Yanai Z. and Gattolliat J.-L., unpublished data). Cloeon smaeleni is the only Cloeon species reported from Saudi Arabia and Yemen (Gillies 1985; Salles et al. 2014). The reports of C. saharense Soldán \&

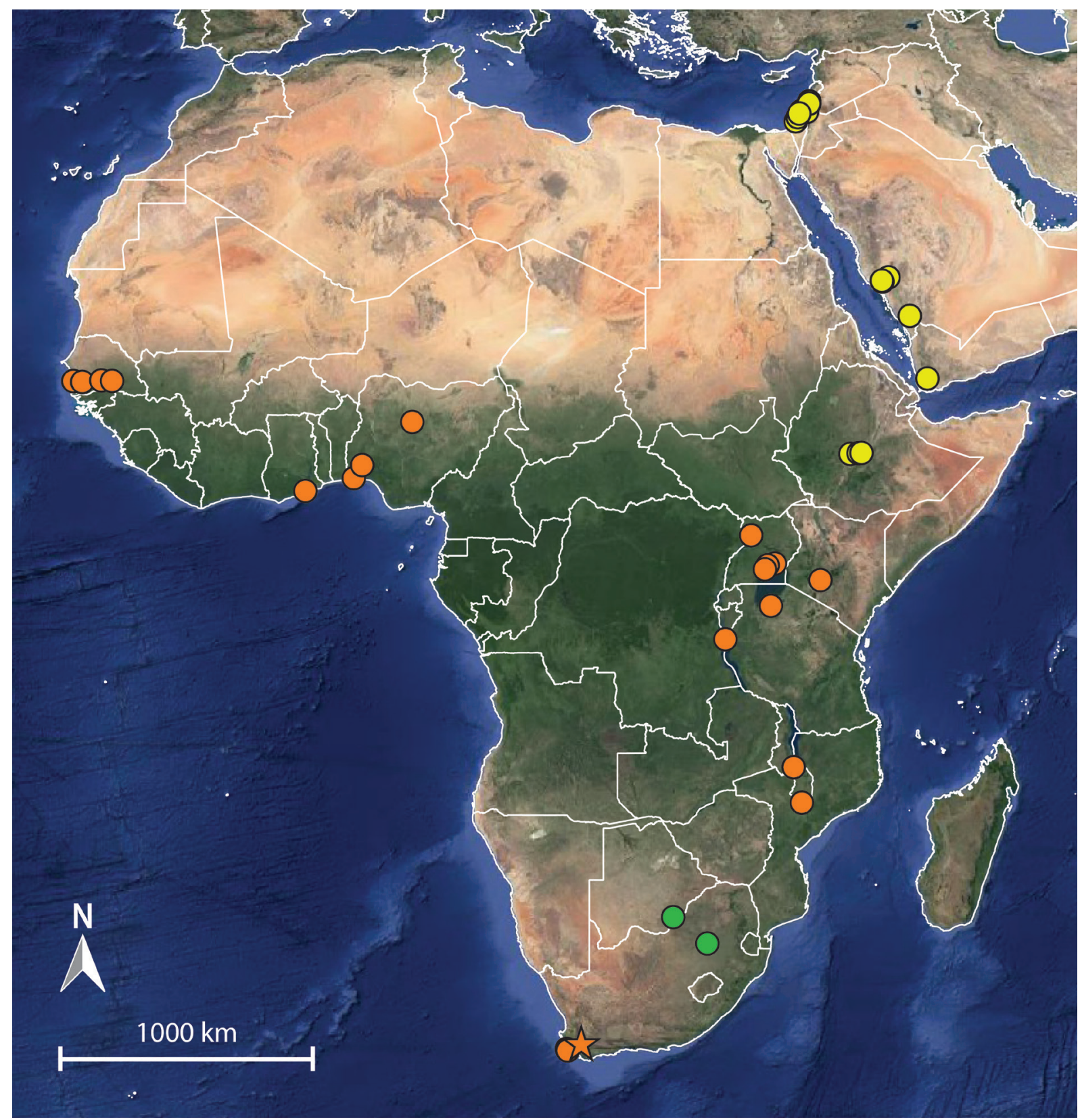

Fig. 2. Reported localities for Cloeon perkinsi. Approximated previously reported localities (orange; star indicates type locality), collecting sites for the present study (yellow), and photograph-based localities (green). Map originated from Google Maps. 
Thomas, 1983 from Israel (Bauernfeind \& Soldán 2012) and Saudi Arabia (Sartori \& Gillies 1990) are most probably based on wrong identifications. No Cloeon findings were reported from Ethiopia prior to now, probably due to lack of mayfly research in the country.

Thanks to the recently collected material, we are able to update the knowledge on the distribution of the species. Fresh material provides us with the opportunity to re-examine the morphological characters of the three important life stages and provide their complete, illustrated description for the first time. Moreover, we were able to sequence mitochondrial COI segments of a few specimens from Israel, Ethiopia and Saudi Arabia. We use the derived information to propose colonisation mechanisms for the spatial pattern present in the north-eastern part of the distribution range.

\section{Material and methods}

This study is based on C. perkinsi material collected in four countries (Fig. 2). The material is housed in the collections of the following institutions: Steinhardt Museum of Natural History, Tel Aviv University, Tel Aviv, Israel (SMNH); Museum of Zoology, Lausanne, Switzerland (MZL); Museum of Natural History, Geneva, Switzerland (MNHG). Material has been morphologically examined in the lab under stereomicroscope and microscope. Morphological identification and measurements below are based on material collected in the main site in Israel (the Hula swamp). This material includes representation of numerous nymphs and adults of both sexes; upon examination, it appears that all morphological descriptions and drawings are valid for material collected in other countries as well.
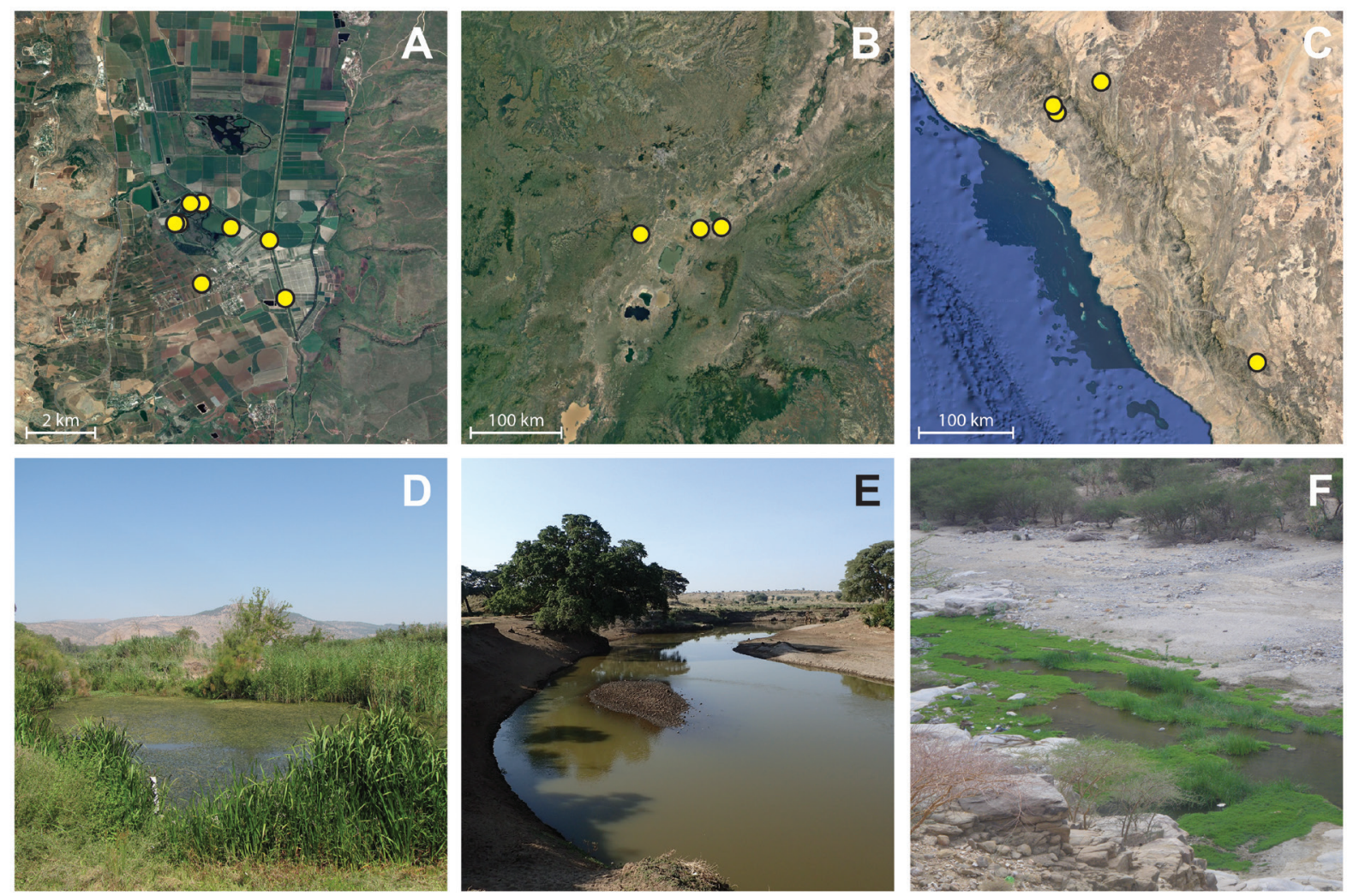

Fig. 3. Habitat general appearance in newly reported populations. A, D. Hula Nature Reserve, Israel. B, E. Awash River, Ethiopia. C, F. Wadi Elarj, Saudi Arabia. Photos by Google (A-C), Yanai Z. (D), Graf W. (E) and Gattolliat J.-L. (F). 
Some individuals were available for molecular study (Table 1), and for them we sequenced the mitochondrial cytochrome $c$ oxidase subunit I (COI), which is used as a popular barcoding sequence. We also used the DNA sequence data to associate different life stages and confirm our morphological identification. In addition to individuals of the focal species, we analysed sequences representing species of all potential Cloeon relatives, as well as other unpublished species from Israel (Table 1). Some of these sequences were obtained from online databases (NCBI GenBank) and others from unpublished information (part of them kindly provided by S. Rutschmann, Leipzig). DNA was extracted following Vuataz et al. (2011) and PCR-amplified with the primers HCO2198 and LCO1490 (Folmer et al. 1994). Optimised PCR conditions included initial denaturation at $94^{\circ} \mathrm{C}$ for $5 \mathrm{~min}, 38$ cycles of denaturation at $95^{\circ} \mathrm{C}$ for $40 \mathrm{~s}$, annealing at $50^{\circ} \mathrm{C}$ for $40 \mathrm{~s}$, and extension at $72^{\circ} \mathrm{C}$ for $40 \mathrm{~s}$, with final extension at $72^{\circ} \mathrm{C}$ for $7 \mathrm{~min}$. Automated sequencing was carried out in Microsynth (Balgach, Switzerland). Sequences were inspected and edited using Geneious Prime v. 2019.0.4 (Biomatters Ltd.) and pairwise distances were calculated using MEGA-X v. 10.0.5 (Kumar et al. 2018) with K2P model. GenBank accession numbers for available online sequences are given in Table 1.

\section{Institutional abbreviations}

SMNH = Steinhardt Museum of Natural History, Tel Aviv University, Tel Aviv, Israel

MZL = Museum of Zoology, Lausanne, Switzerland

MNHG $=\quad$ Museum of Natural History, Geneva, Switzerland

\section{Results}

Class Insecta Linnaeus, 1758

Order Ephemeroptera Hyatt \& Arms, 1891

Family Baetidae Leach, 1815

Genus Cloeon Leach, 1815

Cloeon perkinsi Barnard, 1932

urn:1sid:zoobank.org:act:6778B321-3190-44E4-AB60-A063A3B97FAC

Figs $1,4-8$

\section{Material examined}

Material includes female imagos (ㅇ), female subimagos $\left(\mathbf{s}_{+}\right.$), male imagos $\left({ }^{\Uparrow}\right)$, male subimagos $\left(\mathbf{s}^{\lambda}\right)$, and nymphs of both sexes $(\mathrm{N})$.

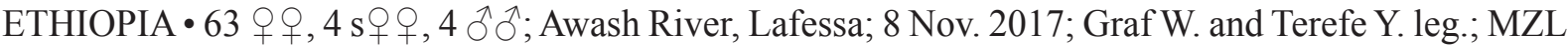

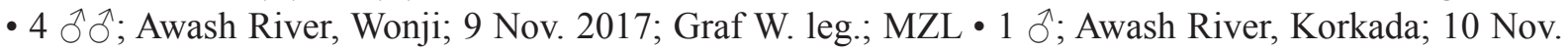
2017; Graf W. leg.; MZL.

ISRAEL • 1 N; Lakhish Stream; 1 Oct. 2014; Elron E. leg.; SMNH • 2 q $;$; Tel-Aviv, Tel-Aviv University botanical gardens; 17 Nov. 2014; Morgulis E. leg.; MZL • 1 \%; same data as for preceding; SMNH - 5 우, $2 \mathrm{~s}$ 우, 6 $\widehat{\jmath}, 8 \mathrm{~N}$; Hula swamp; 1 Dec. 2014; Yanai Z. leg.; SMNH • 1 q; same data as for preceding; MZL • 1 ठ, 1 N; Upper Jordan River; 8 Dec. 2014; Yanai Z. leg.; SMNH • 2 N; Hula swamp; 29 Apr. 2015; Goren L. leg.; SMNH • 1 +, 1 ठ̊; Upper Jordan River; 18 Jul. 2015; Yanai Z. leg.; SMNH

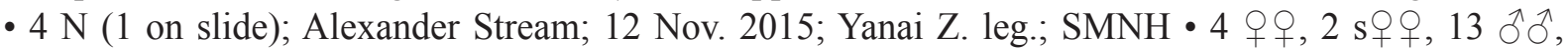

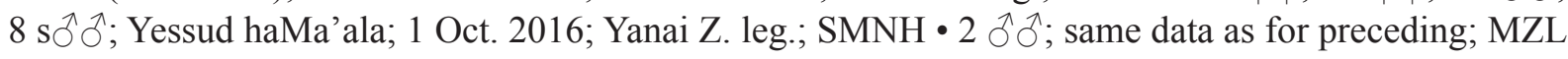
- 24 N (2 on slide); Hula swamp; 16 Nov. 2016; Yanai Z. and Goren L. leg.; SMNH • 6 N; same data as for preceding; MZL • $16 \mathrm{~N}$ (1 on slide); Hula swamp; 17 Nov. 2016; Yanai Z. and Goren L. leg.; SMNH • 7 우, 1 s $\bigcirc^{\top}$; Yessud haMa'ala; 18 Nov. 2016; Yanai Z. leg.; SMNH・ 1 o; same data as for preceding; 
Table 1. Details of examined material for the molecular analysis. None of the listed specimens are type or topotype material.

\begin{tabular}{|c|c|c|c|c|c|}
\hline Species & Country & Locality & Date & Collector(s) & $\begin{array}{c}\text { GenBank } \\
\text { accession } \\
\text { number }\end{array}$ \\
\hline C. perkinsi & Saudi Arabia & Al-Itnayn Dam & 14 Nov. 2012 & Gattolliat J.-L. & MN640623 \\
\hline C. perkinsi & Saudi Arabia & Wadi Buwa & 8 Nov. 2012 & Gattolliat J.-L. & MN640624 \\
\hline C. perkinsi & Saudi Arabia & Wadi Buwa & 8 Nov. 2012 & Gattolliat J.-L. & HG935110 \\
\hline C. perkinsi & Ethiopia & Lafessa & 9 Nov. 2017 & Graf W. & MN640626 \\
\hline C. perkinsi & Israel & Yessud haMa'ala & 1 Oct. 2016 & Yanai Z. & MN640625 \\
\hline C. perkinsi & Israel & Hula & 16 Nov. 2016 & Yanai Z. and Goren L. & MN640634 \\
\hline C. marginale & China & - & - & Zhou D. and Zhou C. & KR612248 \\
\hline C. bicolor & India & - & 17 Dec. 2013 & Selvakumar C. & LC061857 \\
\hline C. simile & The Netherlands & $\begin{array}{l}\text { Z-Kennemerland, } \\
\text { Het Wed }\end{array}$ & 12 Apr. 2018 & Daan Drukker & MN640621 \\
\hline C. simile & Greece & Lamia & 24 Sep. 2011 & $\begin{array}{c}\text { Rutschmann S., Geiger M.F. and } \\
\text { Gritzalis K.C. }\end{array}$ & KU757102 \\
\hline C. simile & Latvia & $\begin{array}{l}20 \mathrm{~km} \text { south of } \\
\text { Liepaja }\end{array}$ & 5 Sep. 2011 & $\begin{array}{c}\text { Rutschmann S., Geiger M.F. and } \\
\text { Kurzrock K. }\end{array}$ & KU757119 \\
\hline C. smaeleni & Madagascar & Antananarivo & 23 May 2003 & Gattolliat J.-L. & HG935104 \\
\hline C. smaeleni & Madagascar & Antananarivo & 23 May 2003 & Gattolliat J.-L. & HG935105 \\
\hline C. smaeleni & Ethiopia & Lafessa & 9 Nov. 2017 & Graf W. & MN640622 \\
\hline C. dipterum s.lat. & Latvia & Daugava River & 7 Sep. 2011 & $\begin{array}{c}\text { Rutschmann S., Geiger M.F. and } \\
\text { Kurzrock K. }\end{array}$ & KJ631634 \\
\hline C. dipterum s.lat. & South Korea & - & 21 May 2013 & Lee J.K. & KF966551 \\
\hline C. dipterum s.lat. & Greece & Kerkini Lake & 25 Sep. 2011 & $\begin{array}{c}\text { Rutschmann S., Geiger M.F. and } \\
\text { Gritzalis K.C. }\end{array}$ & KU757107 \\
\hline C. dipterum s.lat. & Latvia & Kanieris Lake & 8 Sep. 2011 & $\begin{array}{c}\text { Rutschmann S., Geiger M.F. and } \\
\text { Kurzrock K. }\end{array}$ & KJ631637 \\
\hline C. dipterum s.lat. & Greece & $\begin{array}{c}\text { Doïran Lake (North } \\
\text { of Thessalonique) }\end{array}$ & 25 Sep. 2011 & $\begin{array}{c}\text { Rutschmann S., Geiger M.F. and } \\
\text { Gritzalis K.C. }\end{array}$ & KU757105 \\
\hline C. dipterum s.lat. & Slovakia & $\begin{array}{l}\text { Somotor, } \\
\text { Somotorsky canal }\end{array}$ & 16 Aug. 2011 & $\begin{array}{c}\text { Manko P., Rutschmann S. and } \\
\text { Kurzrock K. }\end{array}$ & KJ631639 \\
\hline C. dipterum s.lat. & The Netherlands & $\begin{array}{l}\text { Zwammerdam, } \\
\text { Meije }\end{array}$ & 17 May 2012 & Bram Koese & MN640630 \\
\hline C. dipterum s.lat. & The Netherlands & Utrecht & 9 May 2018 & Daan Drukker & MN640631 \\
\hline C. dipterum s.lat. & Switzerland & $\begin{array}{l}\text { Canton Zurich, } \\
\text { Kleinandelfingen }\end{array}$ & 15 May 2012 & Lubini V. & KJ631625 \\
\hline C. dipterum s.lat. & Russia & St. Petersburg & 27 May 2012 & Przhiboro A. & KU757129 \\
\hline C. dipterum s.lat. & Spain & $\begin{array}{c}\text { Canary Islands, } \\
\text { El Hierro }\end{array}$ & 21 Mar. 2014 & Rutschmann S. and Detering H. & KU757113 \\
\hline C. dipterum s.lat. & Spain & $\begin{array}{l}\text { Canary Islands, } \\
\text { Lanzarote }\end{array}$ & 17 Mar. 2014 & Rutschmann S. and Detering H. & KU757121 \\
\hline C. dipterum s.lat. & Greece & $\begin{array}{l}\text { Kallipéfki (West } \\
\text { slope of Mount } \\
\text { Olympus) }\end{array}$ & 24 Sep. 2011 & $\begin{array}{c}\text { Rutschmann S., Geiger M.F. and } \\
\text { Gritzalis K.C. }\end{array}$ & KU757103 \\
\hline Cloeon sp.1 & Israel & Zarta winter pool & 26 Jan. 2015 & Yanai Z. & MN640627 \\
\hline Cloeon sp.1 & Israel & Roberts winter pool & 10 Apr. 2018 & Kassner Z. and Meresman Y. & MN640628 \\
\hline Cloeon sp.1 & Israel & Yehudiyya stream & 12 Apr. 2018 & Yanai Z. & MN640629 \\
\hline Cloeon sp. 2 & $\begin{array}{l}\text { Palestinian } \\
\text { Authority }\end{array}$ & 'En Fares & 28 May 2018 & Elron E. & MN640632 \\
\hline Cloeon sp.3 & Israel & 'En Boqeq & 10 Jan. 2015 & Yanai Z. & MN640633 \\
\hline
\end{tabular}




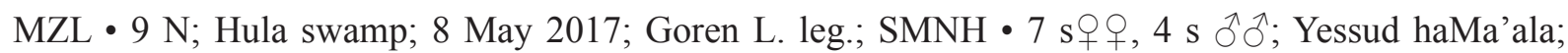
19 Aug. 2017; Yanai Z. leg.; SMNH.

SAUDI ARABIA • 9 N; Wadi Buwa; 8 Nov. 2012; Gattolliat J.-L. leg.; MZL • 2 q +11 sô, 26 N; Wadi Elarj, near Adam; 9 Nov. 2012; Gattolliat J.-L. leg.; MZL・1 so; ‘Al-Itnayn Dam; 14 Nov. 2012; Gattolliat J.-L. leg.; MZL.

YEMEN • 1 ภ’; Ta'izz; 3 Apr. 1998; van Harten A. \& Ahwad A. leg.; MNHG • 1 q; Ta'izz; 30 May 1998; van Harten A. leg.; MNHG • 7 우, 6 ठ̋ ơ; Ta'izz; 24 Jan. 1999; van Harten A. and Ahwad A. leg; MNHG.

\section{Diagnosis}

\section{Nymph}

LENGTH. (based on 30 mature specimens) Body $4.6-6.1 \mathrm{~mm}$, cerci $3.6-4.1 \mathrm{~mm}$, median caudal filament $2.6-4.0 \mathrm{~mm}$.

Colouration. (Fig. 4) General colouration honey-orange to brown. Head brown with light ecru spots and light vermiform mark between compound eyes. Scape and pedicel brown, flagellum ecru. Thorax brown. Legs ivory with distinct brown bands on distal $1 / 3$ of femora and proximal $1 / 3$ of tibiae and tarsi. Base of claws and joints between leg segments dark brown. Abdominal terga relatively uniform, light brown with two central pale yellow spots on posterior terga, tergum $\mathrm{X}$ and sometimes IX almost completely bright. Abdominal sterna ecru to pale brown. Gills milky, semi-transparent, tracheation dark brown. Cerci ecru to light brown with thin ring on each segment, every fourth ring darker; median transversal band absent or very fade in Israel, dark brown in Saudi Arabia.

HEAD. Antennae almost bare (Fig. 5A). Labrum (Fig. 5B) dorsal surface with scattered long setae and setal bases; ventral surface with 7-8 disto-lateral short stout setae, distal margin with row of 25-40 fine long feathered bifid setae. Hypopharynx (Fig. 5E) lingua hemispheric; lingua and superlingua densely covered with short thin hairs; base of superlingua laterally serrated. Left mandible (Fig. 5C) with incisors composed of two sets of four denticles each; prostheca with broad, short denticles and elongated combshaped structure; margin between prostheca and mola with tuft of fine setae. Right mandible (Fig. 5D) with incisors composed of outer and inner sets of four and three denticles respectively, middle denticles of each set more prominent; prostheca with minute pointed denticles; margin between prostheca and mola with tuft of fine setae. Maxillae (Fig. 5F) with three broad, hooked teeth and dentiseta similar

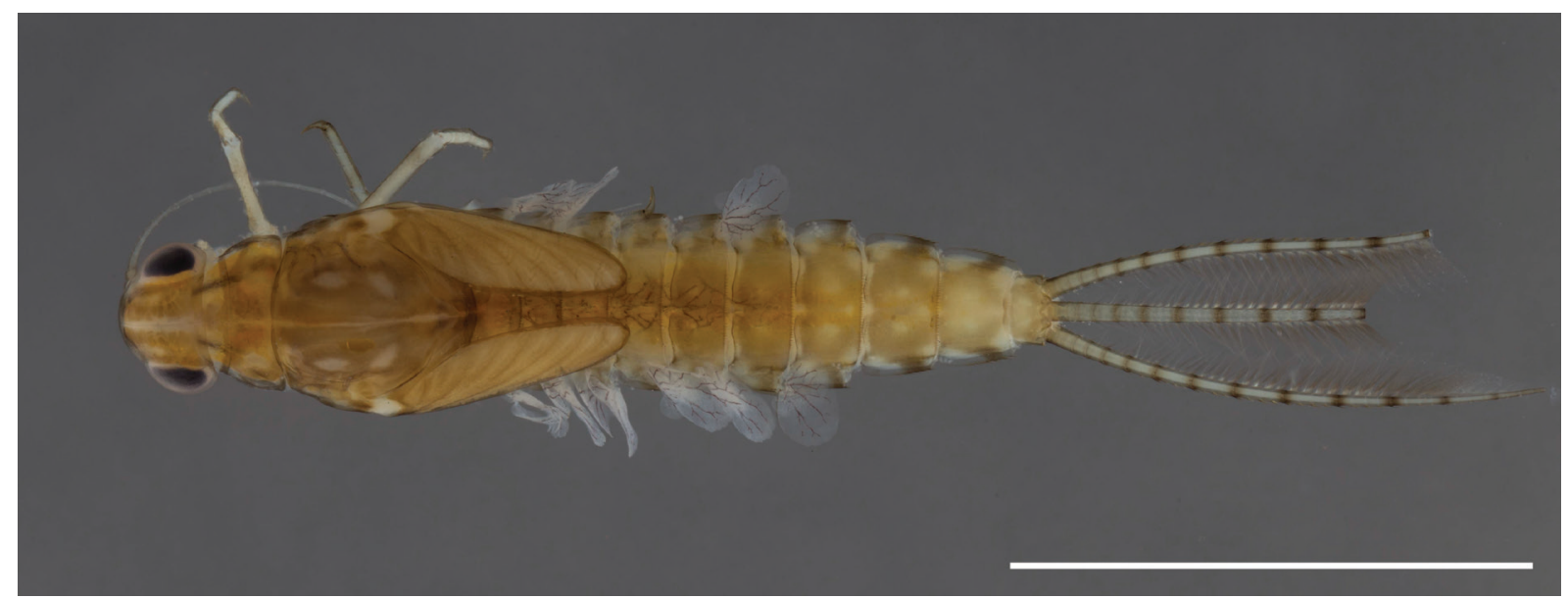

Fig. 4. Cloeon perkinsi, nymph. Habitus. Specimen collected in Hula swamp, Israel. Scale bar $=5 \mathrm{~mm}$. 

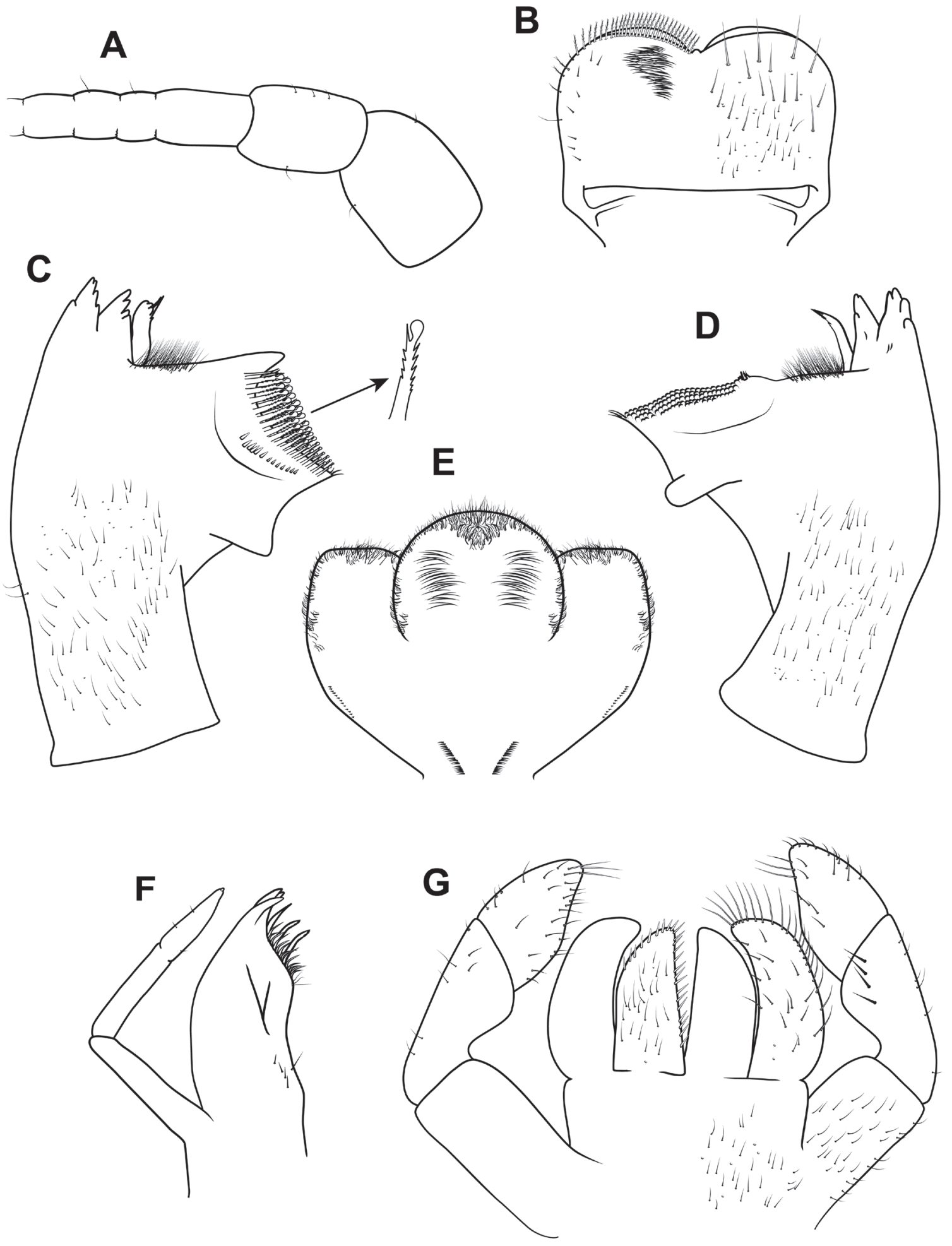

Fig. 5. Cloeon perkinsi, nymph. A. Antennal scape, pedicel and first flagellomeres. B. Labrum (left, ventral; right, dorsal). C. Left mandible (typical molar tooth enlarged). D. Right mandible. E. Hypopharynx. F. Maxilla. G. Labium (left, ventral; right, dorsal). All mouthparts scaled. 
to teeth; lacinia with one row of small setae and long, serrated setae; one row of soft, long, slightly feathered setae and one row of shorter setae; palp three-segmented, segment III with single apical scale. Labium (Fig. 5G) glossae subequal to paraglossae, with scattered ventral thin, long setae; inner margin and apex of glossa with medium, stout setae; paraglossa curved, with 4-6 setae on inner dorsal side and four long simple setae on outer margins. Labial palp three-segmented; segment I shorter than segments II and III combined; segment II with dorsal row of four long, pointed setae; segment III broad and clavate, distal margin with stout, pointed setae; surface of segments II and III with scattered stout setae.

Thorax. Forelegs (Fig. 6A): Coxae bare. Trochanters, femora and tibiae dorsally and ventrally with numerous short, pointed setae; femoral dorsoapical setal patch formed by 4-6 minute setae and a few hair-like setae; no tibial subproximal arc of setae. Tarsi with at least 20 ventral pointed setae; dorsal margin with sparse short, thin setae; one pointed seta, shorter than most ventral setae, on ventral tarsusclaw meeting point. Tarsal claws (Fig. 6B) hooked and elongated, as long as 0.4 tarsus length; with two rows of 9-11 acute teeth, increasing in length toward the apex. Mid and hindlegs similar to forelegs.

ABDomen. Terga I-IX with many scale bases, denser and much more numerous on distal part of tergum; tergal distal margin with row of acute spines of different lengths (Fig. 6F); tergum $\mathrm{X}$ with distal spines arranged in one central and two lateral groups. Sterna I-IX with scattered scale bases. Lateral abdominal margins with no spines on segments I-VII, 5-10 spines on segment VIII, and 8-12 spines on segment IX (Fig. 6G). Gills I-VI with two lamellae; in gill I upper lamella longer than lower lamella; gill VII with one triangular lamella (Fig. 6C-E). Paraproct (Fig. 6H) covered with few fine setae; margin with 15-25 triangular spines; postero-lateral extension with fine setae, margin with 10-20 small triangular spines. Cerci with whorls of spines, lateral spines more prominent.

\section{Adult female}

LENGTH. (based on 13 specimens). Body 5.1-6.3 mm, forewing 4.7-6.3 mm, cerci $6.2-8.9 \mathrm{~mm}$.

Colouration. (Figs 1, 7A-B). Compound eyes dark grey with whitish frame and two reddish cross lines. Head, thorax and abdominal terga I-VIII beige to light brown with longitudinal medium purple-brown stripes as follows (faintly visible on terga VIII-X): two lateral wide stripes starting behind compound eyes, and central stripe forked in two on head, wide on prothorax and narrow on terga, sometimes missing on all or only posterior terga. Abdominal sterna I-VIII white. Legs beige, brownish near joints, femora sometimes with proximal small chestnut-brown spot. Cerci white with dark rings every four segments.

Wings. (Fig. 7C). Costal field uniform light brown; subcostal field solid brown; rest of the wing completely transparent. Veins and cross-veins coppery brown; pterostigma composed of 2-3 crossveins; no cross-veins proximally to main bulla; generally, three cross-veins on subcostal and first radial fields, distal cross-veins not aligning; all marginal intercalaries present and single.

\section{Adult male}

LeNGTH. (based on 15 specimens). Body 4.2-5.6 mm, forewing 4.1-5.3 mm, cerci 7.3-10.0 mm.

Colouration. (Fig. 7D). Head and thorax with chestnut brown to purple stripes, similar to female pattern. Turbinate eyes honey orange. Wings transparent with no pattern, costal and subcostal fields hyaline, veins yellowish. Legs ivory white. Abdominal terga I-VI with two medium purple-brown stripes divided by dorsal white-yellow line, sometimes median narrow dark stripe present, may be fragmented, and may decrease on terga III-IV. Sterna I-VIII white, lateral narrow black line between terga and sterna, posterior segments medium to dark brown. Cerci white with dark rings. 

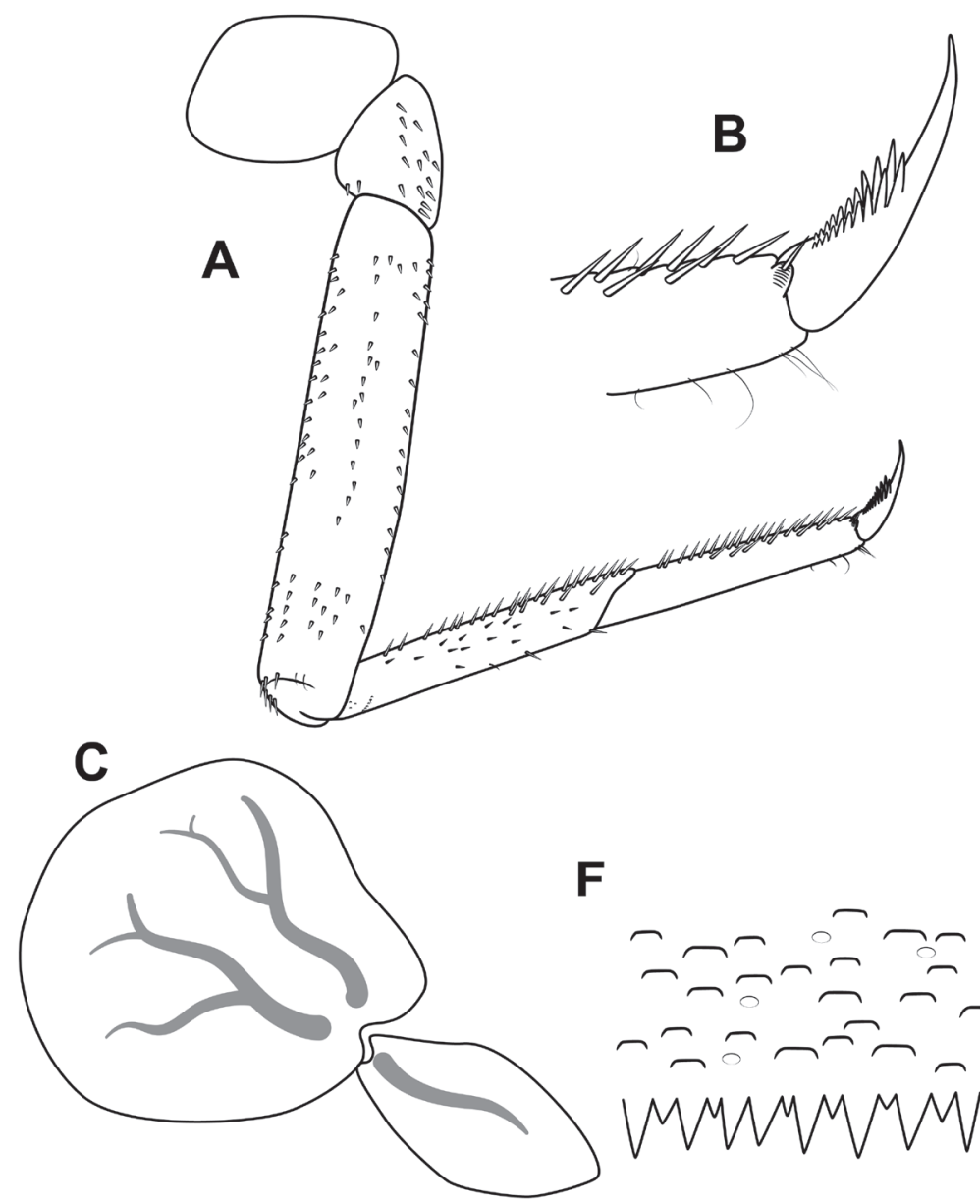

$\mathbf{F}$
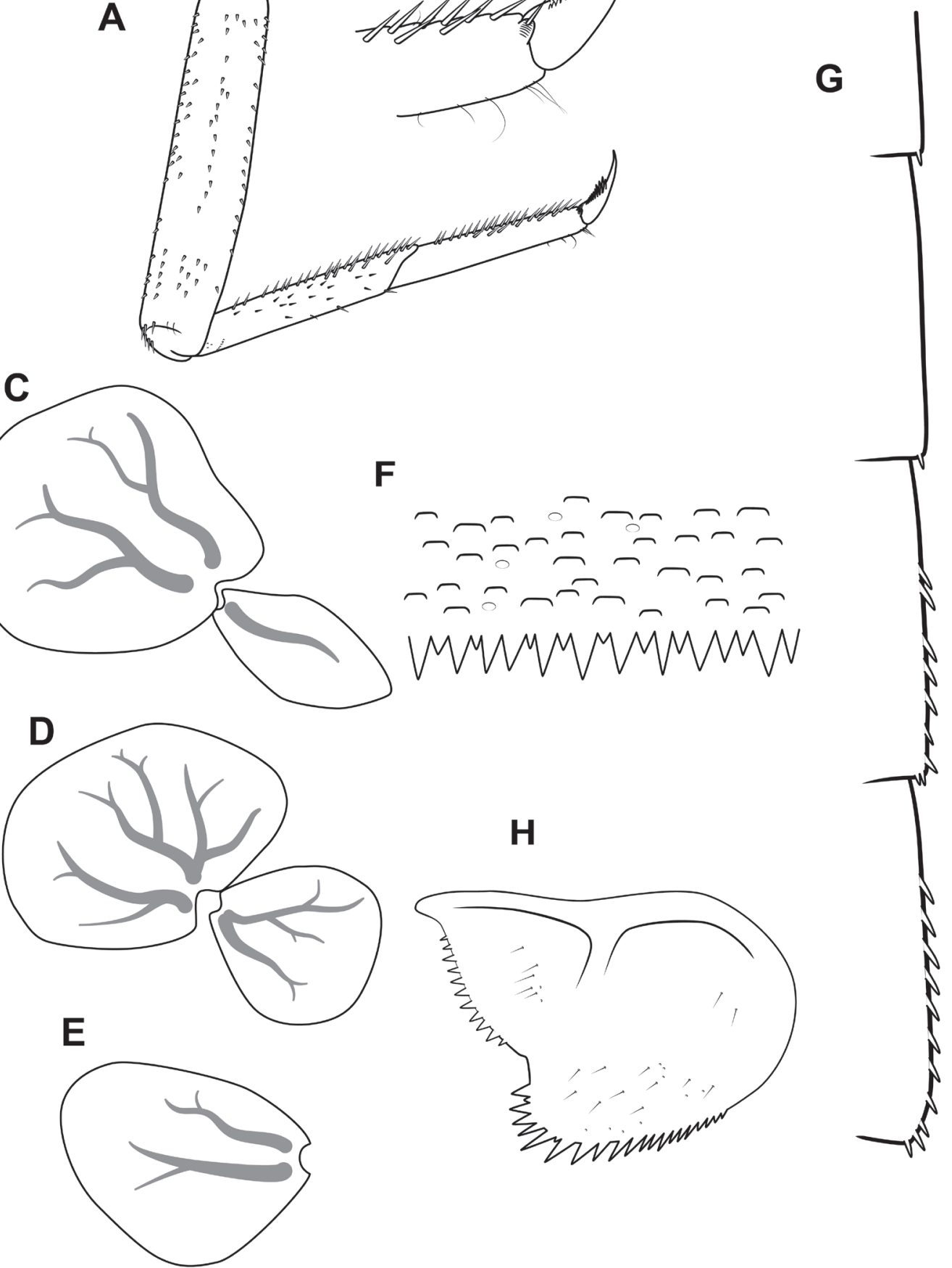

Fig. 6. Cloeon perkinsi, nymph. A. Foreleg. B. Tarsal claw. C. Gill I. D. Gill IV. E. Gill VII. F. Abdominal tergum V, surface and distal margin. G. Lateral abdominal margins (segments VI, VII, VIII, IX). H. Paraproct plate. 

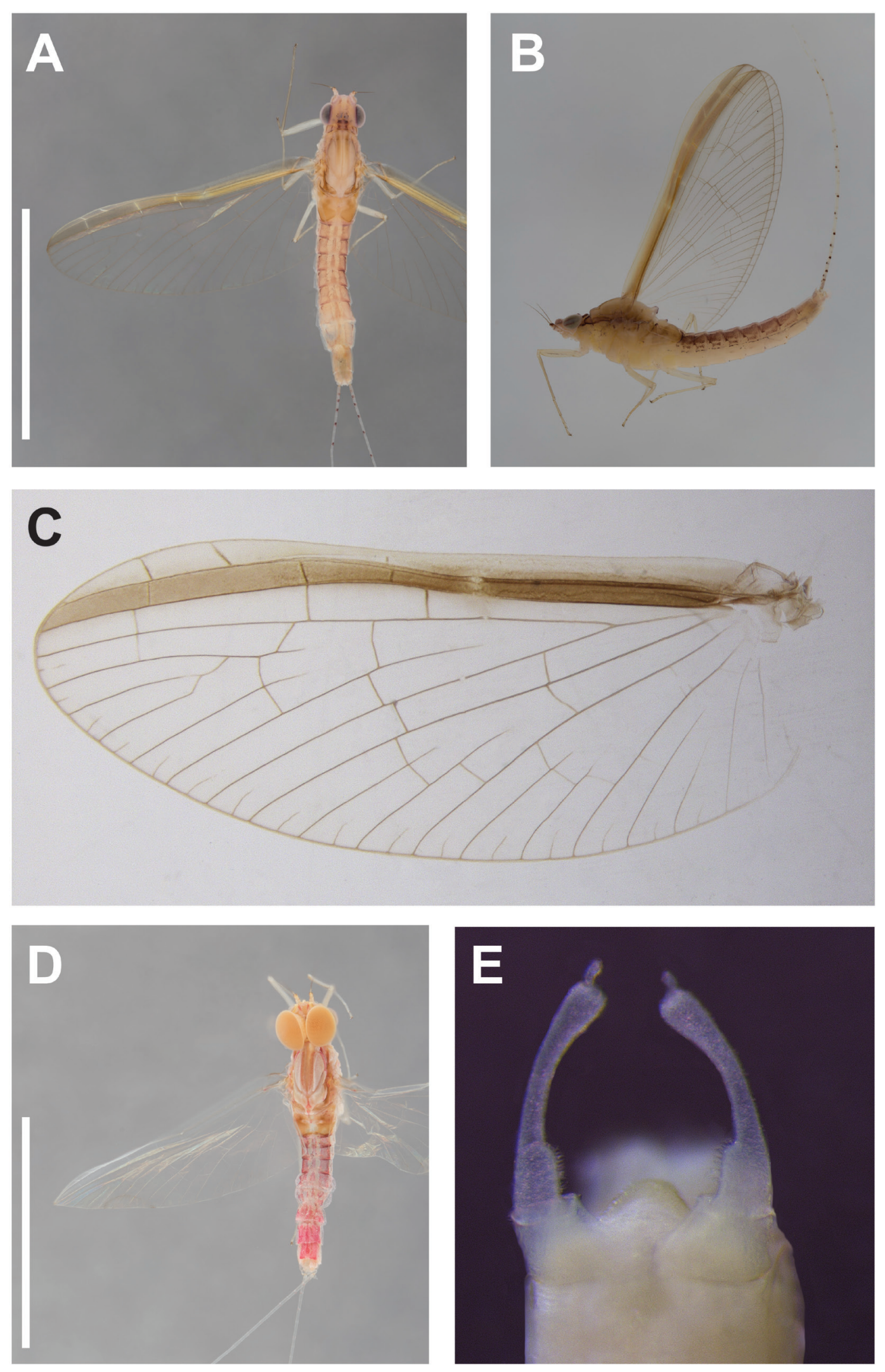

Fig. 7. Cloeon perkinsi, adults. A. $q$ habitus (dorsal). B. $q$ habitus (lateral). C. $q$ forewing. D. $\diamond$ habitus (dorsal). E. ${ }^{\top}$ gonopods. Specimens collected in Yessud haMa'ala, Israel. Scale bars $=5 \mathrm{~mm}$. 
Genitalia. (Fig. 7E). Gonopods three segmented; length of basal gonopod segment and segment I subequal, segment II three times longer than segment I; segments I and II well separated, tip of segment I considerably wider than base of segment II; segment II without spur at base, apex expanded; terminal segment (III) piriform and minute. Genital plate (penis cover) narrower than gap between two basal segments of gonopods.

\section{Molecular analysis}

Blasting the resulted sequences in NCBI and in Barcode of Life Database (BOLD) failed to match similarities higher than $87.7 \%$, meaning that COI sequences of this $C$. perkinsi have never been deposited online before. Comparing to newly obtained sequences of representatives of Cloeon species from the other morphological species groups (see below), we found distances no lower than 14\% (Table 2).

Cloeon perkinsi average intra-group distances were $0.1 \%$ (Saudi Arabia, $\mathrm{n}=3$ ) and $0.7 \%$ (Israel, $\mathrm{n}=2$ ). Inter-group distances were very low between the Ethiopian and Israeli populations $(0.5 \%)$, while the Saudi sequences were more distant (3.9-4.8\%) (Table 2).

\section{Discussion}

\section{Taxonomic discussion}

The following can be considered as the first diagnostic discussion for the species.

For practical identification purposes, Cloeon species can be gathered in groups based on the pattern of the costal and subcostal fields on the female wing. According to this, Cloeon perkinsi (Kimmins 1947) is clearly close to the Afrotropical C. durani Navás, 1926, C. morna Soldán \& Bojková, 2015, C. sidadi Soldán \& Bojková, 2015, C. virgiliae (Barnard, 1932), and to the Oriental C. bengalense Kimmins, 1947, C. bicolor Kimmins, 1947, C. marginale Hagen, 1858, and C. viridis Kimmins, 1947. In most of these species the subcostal field is coloured the same as the costal, though sometimes lighter (dark brown in C. bengalense, pale in C. bicolor, yellow in C. durani, pale amber in C. virgiliae, yellow-green in C. viridis). Nevertheless, $C$. perkinsi presents a subcostal area clearly darker than the costal area (Fig. 7C). Such pattern is shared with two Cape Verde species, C. morna and C. sidadi. Cloeon morna differs by having a subcostal field which is basally dark brown and distally yellowish-brown (Soldán \& Bojková 2015). Indian species with uniform costal and subcostal fields include $C$. bengalense and C. viridis, both with tergal pattern different from C. perkinsi. Two other Oriental species, which may be synonyms, are C. bicolor and C. marginale, which have paler costal and subcostal fields in comparison to C. perkinsi, and their abdomen presents different pattern (Chopra 1924; Kimmins 1947). The uniform colour of the costal and subcostal fields and the absence of hyaline windows surrounding extra crossveins in costal and subcostal fields, differ $C$. perkinsi from the widespread species $C$. dipterum s.lat. as well as from the Afrotropical C. smaeleni Lestage, 1924 and C. bellum Navás, 1931 (Navás 1926; Gillies 1980, 1985; Gattolliat \& Rabeantoandro 2002).

Abdominal pattern is also important for distinguishing male adults. The only other species which has a median pale stripe like in C. perkinsi is C. morna, which appears lighter (Soldán \& Bojková 2015) than C. perkinsi. Cloeon sidadi is not known at the male imago stage, but its male subimago is different in colours and does not possess a distinguishable longitudinal line (Soldán \& Bojková 2015). Cloeon karachiensis Ali, 1970 from Pakistan, only known in its adult male form, is also different from C. perkinsi in its abdominal pattern (Ali 1970). Generally, male adults of African and Asian species are not described in details and sometimes remain completely unknown. Gonopod structure remains the most informative character for comparison, described here for $C$. perkinsi for the first time. This character is also known for C. morna, which has a wider genital plate comparing to C. perkinsi, and its gonopod first and second segments are almost entirely fused. Outside the morphological African 


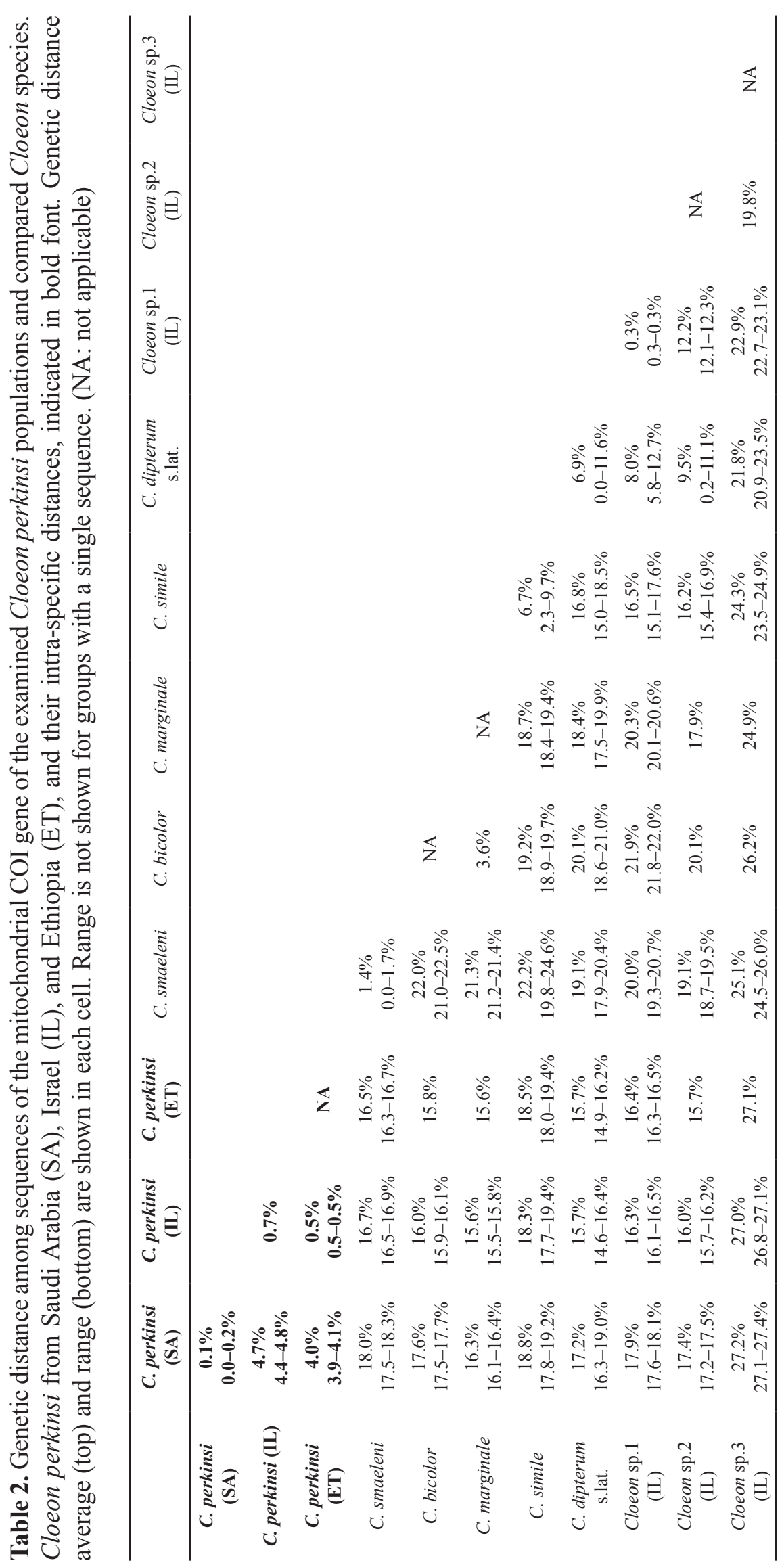


species group determined earlier, it is worth mentioning that in C. perkinsi the penial bridge is apically wider and rounder and the first segment of the gonopod is wider comparing to the Palearctic widespread C. dipterum s.lat. (Sowa 1975).

Important Cloeon nymphal characters include the shape of the labial palp, number of segments in maxillary palp, size and number of denticles on claw, number and arrangement of abdominal lateral spines and gills shape. Gillies (1980) made the first attempt to determine these important nymphal characters for African Cloeon species and conducted very useful comparisons. The shape of labial palp, which he defines as either "tapered" or "clavate", is confusing, even when considering the associated illustrations. Cloeon perkinsi is reported to have tapered labial palpi, like C. gambiae Gillies, 1980 (Gillies 1980), C. orna, C. sidadi (Soldán \& Bojková 2015), and C. emmanueli Lugo-Ortiz and McCafferty, 1998 (Lugo-Ortiz \& McCafferty 1998). However, our examination of the Israeli C. perkinsi nymphs suggests that the labial palpi are more clavate in shape, similarly to C. smaeleni, C. scitulum Kimmins, 1956 (Gillies 1980), and C. tanzaniae Gillies, 1985 (Gillies 1985). This character should be investigated further with a comparison of wide sample of Cloeon species, and until then carefully regarded.

More nymphal characters distinguish C. perkinsi from other African species. Cloeon morna, C. sidadi (from Cape Verde), and C. emmanueli (from Madagascar) have claws with more denticles (at least 15; Lugo-Ortiz \& McCafferty 1998; Soldán \& Bojková 2015). The arrangement and number of lateral spines on the posterior abdominal segments easily distinguish C. perkinsi from the African C. bellum and C. cylindroculum (Kimmins, 1956) (recently assigned to the subgenus Oculogaster Kluge, 2016 (Kluge 2016)), which possess more spines on segments VI-VII (Gillies 1980). On the other hand, C. gambiae, C. morna, and C. scitulum are distinguishable by having fewer spines on segments VIII-IX (Gillies 1980; Soldán \& Bojková 2015). The five morphological characters listed above do not clearly distinguish nymphs of $C$. perkinsi from $C$. smaeleni; the general pattern of abdominal terga, being much more contrasted in the latter (Gattolliat \& Rabeantoandro 2002), seems like the best character to separate the two species at the nymphal stage (as mentioned above, wing pattern of adult females provide the best separation between the two species).

Body pattern and colouration are crucial for the identification of adult Cloeon mayflies, which generally lack noticeable structural characters (with the exception of male gonopods and, to lesser extent, wing venation). With no ability to publish colour photos, authors from early $20^{\text {th }}$ century did their best effort trying to describe patterns and colouration, with occasional hand-drawn low-resolution illustrations. Inevitably, each of them used different terms to define the same colours. In females the dorsal stripes are described as either orange-red, castaneous, reddish-brown, reddish, or brick-red (Barnard 1932), all basically referring to the same shade. Another source of confusion is the abdominal dorsal pattern: Barnard (1932) reports "a narrow medio-dorsal brick-red stripe, laterally a broad stripe of same colour, then a narrow white stripe followed on the pleurae by narrow red line (i.e. there are dorsally five red stripes)". Kimmins (1960) found this pattern on females from one locality, but other populations "show a progressive reduction of the red pigmented pattern until it is much reduced". Kimmins (1960) describes the male pattern as "reddish brown, with two narrow, sinuous, yellow lines...". Both sexes have "red and cream stripes" according to Gillies (1980), who also describes the male terga as "generally pink with a central cream band and often with a median pink line". He further indicates that the pattern in both sexes is variable and the median dark stripe may be lacking. In the material that we examined from Ethiopia and Israel, it seems that such variability does exist, at least regarding the median dark line which may be evident, fragmented, reduced to the posterior 3-4 terga, or even completely lacking. The dorso-lateral stripes are also confusing, often composed of a wide stripe (medium shaded), bordered with two narrower, darker lines. One may count these as a single line (with darker borders not worth mentioning) or as three independent lines (Fig. 8). This natural variation (Kimmins 1960; Gillies 1980) 
in number of lines and personal writing style of authors may lead to reports on two to nine dorsal lines, causing obvious confusion.

Additionally, it is important to notice that mayflies are routinely preserved in liquid (nowadays, $70 \%$ or absolute ethanol is the most widely used), which may alter colours severely over the years; however, the pattern is usually more constant and not expected to change (compare Fig. 1 and Fig. 7A, D). Barnard (1932) and Kimmins (1960) studied mostly alcohol preserved material, the former even expressed his frustration regarding the degraded shape of dried specimens. Gillies $(1980,1985)$, however, provided no information on storage conditions of the material he studied, but only a warning regarding the possible colour change in fluid preserved specimens.

Moreover, our study of $C$. perkinsi from the newly reported countries revealed intraspecific variation in the number of pterostigmatic cross-veins in female wing. While Barnard (1932) reported 4-5, we recorded cases of only 2-3 cross-veins in Ethiopia and Israel. Other important adult characters, such as male genitalia, are unfortunately not reported by Kimmins (1960). In the nymph stage, we noticed variability in the medial transversal band on the cerci, which seems to be more evident in Saudi Arabia

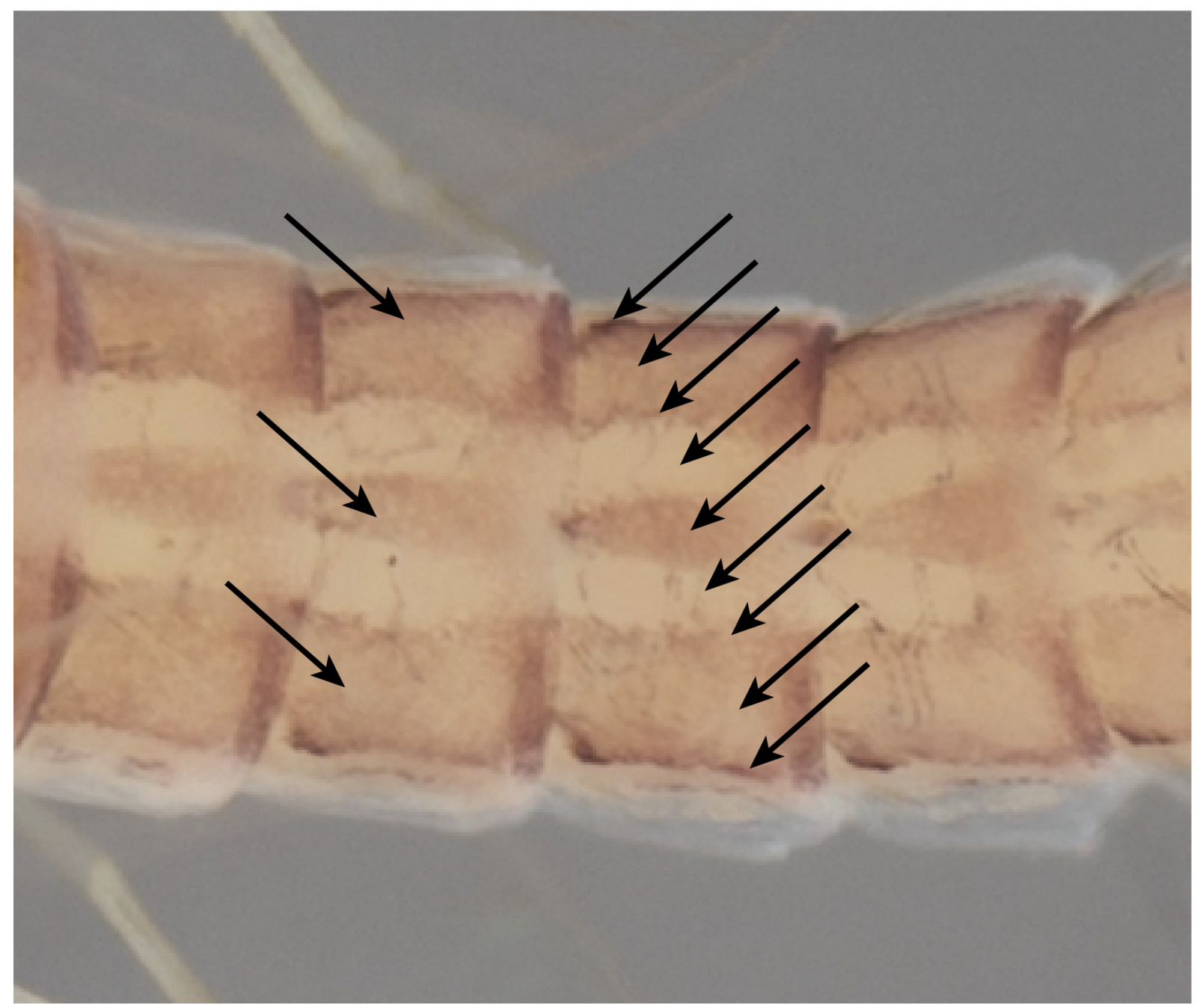

Fig. 8. Cloeon perkinsi, $q$ abdominal terga II-V. Arrows presenting two different methods of counting the lines. Left: counting only the dark stripes (three stripes in total). Right: counting dark and bright stripes, including darker borders of stripes (seven dark lines in total). 
and fade (sometimes completely missing) in West Africa (Gillies 1980) and Israel. These examples suggest that intraspecific variation, as expected in such widespread species, should be reported carefully to avoid confusions.

Nymphs are illustrated by Demoulin (1965) with no specific assignment, and mentioned by Gillies (1980, 1985) with no thorough morphological treatment. The few details given by Gillies (1980) generally fit the nymphs we studied from Ethiopia and Israel, with one disagreement about the shape of the labial palp. It is not clear how exactly Gillies (1980) associated nymphs with the adults he believed were C. perkinsi. Even if the association is correct, with colouration variability of adults, and no attention paid for the shape of male genitalia, Gillies may be wrong in his specific identification. As the nymph of South African C. perkinsi has never been reported, neither Gillies (1980) nor our present study can be certain that we have examined the same species. This is an obvious result of the general lack of diagnostic characters in adult mayflies.

Genetic information for most of the discussed species, including C. perkinsi, is unavailable, with only a handful of species (representing all species morphological groups as mentioned above) being sequenced for the mitochondrial barcode gene COI. The examined populations of $C$. perkinsi clearly belong to neither of these species, with a distance of at least $14 \%$ between them and other available sequences (Table 2).

As expected, the three morphologically similar populations from Israel, Ethiopia and Arabian Peninsula form a genetically monophyletic group; despite the morphological similarity, the Saudi population appears to be genetically more distinct from the other two populations. The COI distance between Saudi Arabia and other countries (3.9-4.8\%) is higher than expected for intra-specific variation, but not high enough to consider them as separate species with certainty (Ball et al. 2005; Ståhls \& Savolainen 2008; Webb et al. 2012). Similar distances have been demonstrated among mayfly populations (Ecdyonurus sp.) which have been split around $2 \mathrm{Ma}$ (Gattolliat et al. 2015). The sample size remains rather restricted; a single haplotype is now known from Saudi Arabia and sequences from most of the distribution range in Africa are not available. We expect to discover additional populations in the future, with genetic features linking the available haplotypes.

\section{Biogeographical discussion}

Cloeon perkinsi is known from southern, western and eastern Africa, and reported as a common and abundant species (Barnard 1932; Kimmins 1960; Gillies 1980, 1985). It is reasonable to assume that it is also common in the less studied regions of central Africa. With the new geographical information presented here, the known distribution of $C$. perkinsi now includes the southern Levant and the southwest of the Arabian Peninsula. The latter region, although not in continental Africa, is considered Afrotropical, thus this species displays a typical widespread continental Afrotropical distribution (it is not yet known from Afrotropical islands). In the north-easternmost limit of its range, C. perkinsi exhibits a fragmented distribution pattern, based on allopatric patches of variable habitat types.

Cloeon species are known for colonising large ranges of habitat types and environmental conditions, medium and rapid currents excluded. Cloeon perkinsi occupies habitats of variable nature, including standing and running waters, in perennial and ephemeral waterbodies (Barnard 1940; Kimmins 1960; Gillies 1980, 1985; Fig. 3). Wide geographical distribution is also not surprising for Cloeon, one of the best mayfly colonisers (Landa \& Soldán 1986) with longest flying period; a C. perkinsi female is recorded to live for 54 days after emergence (Barnard 1940). Fragmented distribution patterns are rare in widespread mayflies, and are usually due to lack of suitable habitats. While the absence of C. perkinsi can be understood in the vast Arabian and Saharan deserts, the question remains, why many suitable habitats in regions like northern Israel are uncolonised. Sporadic findings of few individuals $(<5$ per 
site) in remote sites in Israel suggest that $C$. perkinsi is able to disperse as efficiently as other Cloeon species, but seems to fail in sustaining populations in these new habitats. A possible explanation for that can be intra-generic competition, e.g. with an undescribed local species of $C$. dipterum s.lat.

Cloeon perkinsi is not the only aquatic insect displaying this distribution pattern. Similarly, the baetid mayflies Cloeon smaeleni and Labiobaetis glaucus (Agnew, 1961) are two Afrotropical species, widely distributed in Continental Africa, which are also reported from Saudi Arabia (Salles et al. 2014; Gattolliat et al. 2018). The strong affinities between Africa and the southern part of the Arabian Peninsula are demonstrated also in other aquatic insects, such as some caddisflies (Trichoptera) (Botosaneanu 1992; Malicky 1986). For example, the caddisfly Hydroptila cruciata Ulmer, 1912 is reported from vast areas in West, East, and Southern Africa, Madagascar, Arabian Peninsula, and the Levant (Malicky 1986; Tobias \& Tobias 2019). This species has no specific ecological requirements and occurs in habitats ranging from small headwaters to large rivers, in rainforests or deserts, with no specific altitudinal preference (Botosaneanu 2002). All three above-mentioned species co-occur with C. perkinsi at the Awash River, Ethiopia (Graf \& Terefe, unpublished data).

The African origin of $C$. perkinsi is supported by morphology; in particular, the female wing pattern which clearly assigns it close to the Afrotropical C. morna and C. sidadi. Based on the genetic distances calculated, a few distribution shaping scenarios possibly explain the colonisation in the Levant and Arabian Peninsula. Split of the Saudi populations from those of Israel and Ethiopia must have happened during the late Pliocene or early Pleistocene, at least $1.2 \mathrm{Ma}$ (dated by applying a "standard" mitochondrial DNA clock estimated at 2.3\% My-1, given by Papadopoulou et al. 2010). Similar genetic distances (4\%) have been shown on Ecdyonurus mayflies which split 2.0 Ma in Corsica and Sardinia (Gattolliat et al. 2015). Southern areas of the Arabian Peninsula and eastern coasts of Africa were last directly connected via the Bab El-Mandab bridge over the Red Sea (10-5.3 Ma), but the last gene flow was still possible millions of years later, probably thanks to occasional decreases in sea level (Rohling et al. 1998), creating bridges over the Red Sea, some as recent as 18 kya (Thunell et al. 1988; Flemming et al. 2003). Given enough time and assisted by wind, Cloeon adults are known to cross long oversea distances (Monaghan et al. 2005; Gattolliat \& Staniczek 2011; Rutschmann et al. 2014; Gattolliat et al. 2015). Link northward to the Levantine populations could have been possible under more humid conditions, which repeatedly occurred over the Pleistocene and Holocene, until 6 kya (Por 1975; Sanlaville 1992; Frumkin \& Comay 2019); but relict populations of C. perkinsi in the Arabian Peninsula were already isolated at this time. The genetic proximity of the Ethiopian and Israeli samples could have only been possible due to recent gene flow, supporting migration northwards along the Great Rift Valley during the Pleistocene (as suggested by Botosaneanu (1999) rather than earlier-migration theories suggested by Heller (2007)).

The $2700 \mathrm{~km}$ separating these two localities nowadays were more suitable for aquatic insects in the near past, as climatic conditions had changed rapidly throughout the Pleistocene and Holocene, alternately enabling humid savannas with large water bodies up until 6-4.5 kya (Pachur \& Kröpelin 1987; Ritchie \& Haynes 1987; Frumkin \& Comay 2019). Cloeon perkinsi could have used occasional subtropical oases as 'step-stones' via eastern Sahara and the Sinai Peninsula, an area which also experienced more rainfall than the present day (Por 1975; Hassan 1997). It is also possible that the connection between East Africa and the Levant is still maintained via undocumented populations; 'Cloeon kaheriensis' or 'C. moursii', nomina nuda mentioned (but not formally described) by Hassan \& Abdel Fattah (2007) from Egypt, may be a clue for one of these missing links. Understanding the biogeography and colonisation history of $C$. perkinsi (and freshwater invertebrates in general) in the region is limited mainly due to lack of current research and poor collecting efforts in some countries (e.g. parts of the Arabian Peninsula, Egypt, Sudan, South Sudan). 
We conclude that the most reasonable scenario for $C$. perkinsi colonisation north-eastwards pattern began with an African origin, followed by spread northwards and eastwards in more humid eras. In the following dry periods, the species was able to sustain populations only in humid tropical-like refugia. The combination of the Red Sea and the arid Arabian conditions isolated the Saudi population. The Levantine populations remained connected to the ancestral African populations until recently, or they have resulted from a recent stepping-stone colonisation. Genetic isolation of the Saudi population suggests that the Red Sea functions as a much important barrier comparing to the Sahara-Arabian deserts.

The Jordan Valley and Hula swamp are unique hot and humid habitats in the Levant (Dimentman et al. 1992). Cloeon perkinsi is hence a typical tropical species with relict populations in a no-longer tropical region, or a tropical opportunist which established sustainable populations in tropical enclaves. Either way, it represents a rare biological element in the Levant and Arabia, and highlights the conservation value of the tropical refugia it occupies in these regions, which support other tropical elements as well.

The present study provides more information on the north-eastern limit of distribution for C. perkinsi and illuminates a probable process of colonising this region. Comparing fresh material from South Africa and elsewhere in Africa can either confirm the large intraspecific variability of a very widespread species, or provide information to claim that more than one species exists in this group. Given that the nymphs are not described from South Africa, it is highly possible that the nymphs reported from East Africa (Gillies 1985 ) and/or in the current study actually belong to another species. Further morphological and genetic study is needed to solve these issues.

\section{Acknowledgments}

We thank Helen Barber-James (for a fruitful discussion), Hathal M. Al-Dhafer (organising field trip in Saudi Arabia), Netta Dorchin (supporting sampling in Israel), Liron Goren (sampling material in Israel), Pieter Kotzee (photos in Fig. 1), Marion Podolak (technical assistance), and Sereina Rutschmann (providing unpublished sequences). This work was supported by the Swiss Government Excellence Scholarship (FCS granted to Zohar Yanai). Material was collected in Israel under collecting permits number 40223, 40720, 41168, 41547, and 41897 by the Israel Nature and Parks authority. Fieldwork in Israel was supported by the Israel Taxonomy Initiative (ITI). Fieldwork in Ethiopia was conducted under the auspices of the LARIMA - Sustainable Highland Rivers Management in Ethiopia (Project Number 106), a project funded by the Austrian Partnership Programme in Higher Education and Research for Development (APPEAR) of the Austrian Development Cooperation (ADC) and the Austrian Agency for International Cooperation in Education and Research (OeAD).

\section{References}

Ali R. 1970. Certain mayflies (order: Ephemeroptera) of west Pakistan. Pakistan Journal of Science 22: $119-124$.

Ball S.L., Hebert P.D.N., Burian S.K. \& Webb J.M. 2005. Biological identifications of mayflies (Ephemeroptera) using DNA barcodes. Journal of the North American Benthological Society 24: 508524. https://doi.org/10.1899/04-142.1

Barber-James H.M., Gattolliat J.-L., Sartori M. \& Hubbard M.D. 2008. Global diversity of mayflies (Ephemeroptera, Insecta) in freshwater. Hydrobiologia 595: 339-350.

https://doi.org/10.1007/s10750-007-9028-y

Barnard K.H. 1932. South African may-flies (Ephemeroptera). Transactions of the Royal society of South Africa 20: 201-259. https://doi.org/10.1080/00359193209518858 
Barnard K.H. 1940. Additional records, and descriptions of new species, of South African alder-flies (Megaloptera), May-flies (Ephemeroptera), caddis-flies (Trichoptera), stone-flies (Perlaria), and dragonflies (Odonata). Annals of the South African Museum 32: 609-661.

Bauernfeind E. \& Soldán T. 2012. The Mayflies of Europe (Ephemeroptera). Apollo Books, Ollerup. https://doi.org/10.1163/9789004260887

Botosaneanu L. 1992. Fauna Palaestina, Insecta VI: Trichoptera of the Levant. The Israel Academy of Sciences and Humanities, Jerusalem.

Botosaneanu L. 1999. Caddisflies (Trichoptera) - what can they tell about biogeography of the Levant? Israel Journal of Zoology 45: 75-78.

Botosaneanu L. 2002. A classical case of insular radiation: the Hydroptila species of La Réunion. Proceedings of the $10^{\text {th }}$ International Symposium on Trichoptera, Nova Supplementa Entomologica 15: 323-330.

Chopra B. 1924. The fauna of an island in the Chilka Lake. The Ephemeroptera of Barkuda Island. Records of the Indian Museum 26: 415-422.

Demoulin G. 1965. LXXXVIII. - Ephemeroptera. in: Basilewsky P. \& Lelup N.(eds) Mission zoologique de l'I.R.S.A.C. en Afrique orientale: 91-114. Royal Museum for Central Africa, Tervuren.

Dimentman C., Bromley H.J. \& Por F.D. 1992. Lake Hula - reconstruction of the fauna and hydrobiology of a lost lake. The Israel Academy of Sciences and Humanities, Jerusalem.

Dumont H.J. 1991. Fauna Palaestina, Insecta V: Odonata of the Levant. The Israel Academy of Sciences and Humanities, Jerusalem.

Flemming N.C., Bailey G.N., Courtillot V., King G., Lambeck K., Ryerson F. \& Vita-Finzi C. 2003. Coastal and marine palaeo-environments and human dispersal points across the Africa-Eurasia boundary. In: Brebbia CA, Gambin T (eds.) The maritime and underwater heritage: 61-74. Wessex Institute of Technology, Southampton.

Folmer O., Black M., Hoeh W., Lutz R. \& Vrijenhoek R. 1994. DNA primers for amplification of mitochondrial cytochrome c oxidase subunit I from diverse metazoan invertebrates. Molecular Marine Biology and Biotechnology 3: 294-299.

Frumkin A. \& Comay O. 2019. The last glacial cycle of the southern Levant: Paleoenvironment and chronology of modern humans. Journal of Human Evolution. https://doi.org/10.1016/j.jhevol.2019.04.007

Gattolliat J.-L. \& Rabeantoandro S.Z. 2002. The genus Cloeon (Ephemeroptera, Baetidae) in Madagascar. Mitteilungen der Schweizerischen Entomologischen Gesellschaft 74: 195-209.

Gattolliat J.-L. \& Staniczek A.H. 2011. New larvae of Baetidae (Insecta: Ephemeroptera) from Espiritu Santo, Vanuatu. Stuttgarter Beiträge zur Naturkunde A, Neue Serie 4: 75-82.

Gattolliat J.-L., Vuataz L. \& Sartori M. 2012. First contribution to the mayflies of Jordan. Zoology in the Middle East 56: 91-110. https://doi.org/10.1080/09397140.2012.10648945

Gattolliat J.-L., Cavallo E., Vuataz L. \& Sartori M. 2015. DNA barcoding of Corsican mayflies (Ephemeroptera) with implications on biogeography, systematics and biodiversity. Arthropod Systematics \& Phylogeny 73: 3-18.

Gattolliat J.-L., Kondratieff B.C., Kaltenbach T. \& Al Dhafer H.M. 2018. Labiobaetis from the Kingdom of Saudi Arabia (Insecta, Ephemeroptera, Baetidae). ZooKeys 774: 77-104.

https://doi.org/10.3897/zookeys.774.25273 
Gillies M.T. 1980. An introduction to the study of Cloeon Leach (Baetidae, Ephemeroptera) in West Africa. Bulletin de l'Institut Francaise d'Afrique Noire 42: 135-156.

Gillies M.T. 1985. A preliminary account to the East African species of Cloeon Leach and Rhithrocloeon gen.n. (Ephemeroptera). Aquatic Insects 7: 1-17. https://doi.org/10.1080/01650428509361193

Goren M. \& Ortal R. 1999. Biogeography, diversity and conservation of the inland water fish communities in Israel. Biological Conservation 89: 1-9. https://doi.org/10.1016/S0006-3207(98)00127-X

Hassan F.A. 1997. Holocene palaeoclimates of Africa. African Archaeological Review 14: 213-230. https://doi.org/10.1023/A:1022255800388

Hassan S.A. \& Abdel Fattah M.A. 2007. A revision of the order Ephemeroptera from Egypt. Journal of the Egyptian-German Society of Zoology 53: 189-214.

Heller J. 2007. A historic biogeography of the aquatic fauna of the Levant. Biological Journal of the Linnean Society 92: 625-639. https://doi.org/10.1111/j.1095-8312.2007.00850.x

Kimmins D.E. 1947. New species of Indian Ephemeroptera. Proceedings of the Royal Entomological Society of London (B) 16: 92-100. https://doi.org/10.1111/j.1365-3113.1947.tb00865.x

Kimmins D.E. 1955. Ephemeroptera from Nyasaland, with description of three new and some interesting nymphal forms. Annals and Magazine of Natural History 12: 859-880.

https://doi.org/10.1080/00222935508655706

Kimmins D.E. 1960. Notes on East African Ephemeroptera, with descriptions of new species. Bulletin of the British Museum (Natural History), Entomology 9: 337-355. https://doi.org/10.5962/bhl.part.27555

Kluge N.J. 2016. A new subgenus Oculogaster subgen.n. for viviparous representatives of Procloeon s.lat., with discussion about status of the generic name Austrocloeon Barnard, 1932 and the species name africanum Esben-Petersen, 1913 [Cloeon] (Ephemeroptera, Baetidae). Zootaxa 4107: 491-516.

https://doi.org/10.11646/zootaxa.4107.4.2

Kluge N.J. 2019. Ephemeroptera of the World. Available from http://www.insecta.bio.spbu.ru/z/Eph-spp/Contents.htm [accessed 20 June 2019]

Kumar S., Stecher G., Li M., Knyaz C. \& Tamura K. 2018. MEGA X: Molecular Evolutionary Genetics Analysis across computing platforms (Version 10.0.2). Molecular Biology and Evolution 35: 15471549. https://doi.org/10.1093/molbev/msy096

Landa V. \& Soldán T. 1986. Invasive behavioural patterns of mayflies (Insecta, Ephemeroptera) in some man-influenced aquatic biotopes in Czechoslovakia. Ekologia 3: 239-246.

Lugo-Ortiz C.R. \& McCafferty W.P. 1998. New species of Cloeon and Demoulinia (Ephemeroptera: Baetidae) from Madagascar. Entomological News 109: 357-362.

Malicky H. 1986. The caddisflies of Saudi Arabia and adjacent regions (Insecta, Trichoptera). Fauna of Saudi Arabia 8: 233-245.

Monaghan M.T., Gattolliat J.-L., Sartori M., Elouard J.-M., James H., Derleth P., Glaizot O., de Moor F. \& Vogler A.P. 2005. Trans-oceanic and endemic origins of the small minnow mayflies (Ephemeroptera, Baetidae) of Madagascar. Proceedings of the Royal Society B 272: 1829-1836.

https://doi.org/10.1098/rspb.2005.3139

Navás L. 1926. Algunos insectos del Museo de Paris. Serie 3. Brotéria (Série Zoológica) 23: 95-115. 
Pachur H.J. \& Kröpelin S. 1987. Wadi Howar: Paleoclimatic evidence from an extinct river system in the southeastern Sahara. Science 237: 298-300. https://doi.org/10.1126/science.237.4812.298

Papadopoulou A., Anastasiou I. \& Vogler A.P. 2010. Revisiting the insect mitochondrial molecular clock: the Mid-Aegean trench calibration. Molecular Biology and Evolution 27: 1659-1672.

https://doi.org/10.1093/molbev/msq051

Por F.D. 1975. An outline of the zoogeography of the Levant. Zoologica Scripta 4: 5-20.

https://doi.org/10.1111/j.1463-6409.1975.tb00713.x

Ritchie J.C. \& Haynes C.V. 1987. Holocene vegetation zonation in the eastern Sahara. Nature 330: 645-647. https://doi.org/10.1038/330645a 0

Rohling E.J., Fenton M., Jorissen F.J., Bertrand P., Ganssen G. \& Caulet J.P. 1998. Magnitudes of sealevel lowstands of the past 500,000 years. Nature 394: 162-165. https://doi.org/10.1038/28134

Rutschmann S., Gattolliat J.-L., Hughes S.J., Báez M., Sartori M. \& Monaghan M.T. 2014. Evolution and island endemism of morphologically cryptic Baetis and Cloeon species (Ephemeroptera, Baetidae) on the Canary Islands and Madeira. Freshwater Biology 59: 2516-2527. https://doi.org/10.1111/fwb.12450

Rutschmann S., Detering H., Simon S., Funk D.H., Gattolliat J.-L., Hughes S.J., Raposerio P.M., Desalle R., Sartori M. \& Monaghan M.T. 2017. Colonization and diversification of aquatic insects on three Macaronesian archipelagos using 59 nuclear loci derived from a draft genome. Molecular Phylogenetics and Evolution 107: 27-38. https://doi.org/10.1016/j.ympev.2016.10.007

Salles F.F., Gattolliat J.-L., Angeli K.B., De-Souza M.R., Gonçalves I.C., Nessimian J.L. \& Sartori M. 2014. Discovery of an alien species of mayfly in South America (Ephemeroptera). ZooKeys 399: 1-16. https://doi.org/10.3897/zookeys.399.6680

Samocha M. 1972. Ephemeroptera of Israel. Master's thesis, Tel Aviv University, Israel.

Sanlaville P. 1992. Changements climatiques dans la Péninsule Arabique durant le Pléistocène supérieur et l'Holocène. Paléorient 18: 5-26. https://doi.org/10.3406/paleo.1992.4560

Sartori M. \& Gillies M.T. 1990. Further records of mayflies (Insecta: Ephemeroptera) from the Arabian Peninsula. Leptophlebiidae and Baetidae. Fauna of Saudi Arabia 11: 10-17.

Ståhls G. \& Savolainen E. 2008. mtDNA COI barcode reveal cryptic diversity in the Baetis vernus group (Ephemeroptera, Baetidae). Molecular Phylogenetics and Evolution 46: 82-87.

https://doi.org/10.1016/j.ympev.2007.09.009

Soldán T. \& Bojková J. 2015. New species of mayflies (Ephemeroptera) from Cape Verde. Zootaxa 3926: 561-575. https://doi.org/10.11646/zootaxa.3926.4.6

Sowa R. 1975. What is Cloeon dipterum (Linnaeus, 1761)? The nomenclatural and morphological analysis of a group of the European species of Cloeon Leach (Ephemerida: Baetidae). Entomologica Scandinavica 6: 215-223. https://doi.org/10.1163/187631275X00046

Thomas J.D. 1966. Some preliminary observations on the fauna and flora of a small man-made lake in the West African savanna. Bulletin de l'IFAN 28: 542-562.

Thunell R.C., Locke S.M. \& Williams D.F. 1988. Glacio-eustatic sea-level control on Red Sea salinity. Nature 334: 601-604. https://doi.org/10.1038/334601a0

Tobias D. \& Tobias W. 2019. Trichoptera Africana. Available from

http://trichoptera.insects-online.de/Trichoptera\%20africana/index.htm [accessed 8 July 2019] 
Vuataz L., Sartori M., Wagner A. \& Monaghan M.T. 2011. Toward a DNA taxonomy of alpine Rhithrogena (Ephemeroptera: Heptageniidae) using a mixed yule-coalescent analysis of mitochondrial and nuclear DNA. PLoS ONE 6: e19728. https://doi.org/10.1371/journal.pone.0019728

Webb J.M., Jacobus L.M., Funk D.H., Zhou X., Kondratieff B., Geraci C.J., DeWalt R.E., Baird D.J., Richard B., Phillips I. \& Hebert P.D.N. 2012. A DNA barcode library for North American Ephemeroptera: progress and prospects. PLOS ONE 7: e38063. https://doi.org/10.1371/journal.pone.0038063

Manuscript received: 17 August 2019

Manuscript accepted: 18 November 2019

Published on: 17 March 2020

Topic editor: Gavin Broad

Desk editor: Jeroen Venderickx

Printed versions of all papers are also deposited in the libraries of the institutes that are members of the EJT consortium: Muséum national d'histoire naturelle, Paris, France; Meise Botanic Garden, Belgium; Royal Museum for Central Africa, Tervuren, Belgium; Royal Belgian Institute of Natural Sciences, Brussels, Belgium; Natural History Museum of Denmark, Copenhagen, Denmark; Naturalis Biodiversity Center, Leiden, the Netherlands; Museo Nacional de Ciencias Naturales-CSIC, Madrid, Spain; Real Jardín Botánico de Madrid CSIC, Spain; Zoological Research Museum Alexander Koenig, Bonn, Germany; National Museum, Prague, Czech Republic. 